\title{
INTERPRETING IN CRIMINAL CASES IN JAPAN: PAST, PRESENT, AND FUTURE PROSPECTS
}

\author{
Makiko MIZUNO, Professor \\ Kinjo Gakuin University \\ Department of English, College of Humanities \\ 15-30, 2-chome, Obata-minami, Moriyama-ku, Nagoya, Japan \\ m-mizuno@kinjo-u.ac.jp
}

\begin{abstract}
In the extant literature in Japan, the description of criminal cases involving foreigners goes back to around the fifth century; however, detailed depictions of language problems requiring legal interpreters started to appear in the Edo period (1603-1868). The cases of an Italian missionary who entered Japan illegally in 1709 and the robbery of Ainu graves by British consular officers in 1865 presented communication difficulties between the interrogator and accused in criminal procedures. This is common even today. This paper introduces the history of legal interpreting with reference to high profile cases, and reviews changes in communication issues in criminal proceedings involving non-Japanese speaking defendants in modern Japan. It also presents prospects regarding the shift in attitude among legal practitioners toward legal interpreting against the backdrop of recent judicial reforms including the introduction of a lay judge system and visualisation of the investigation process.
\end{abstract}


Key words: history, criminal procedures, communication difficulty, legal interpreting, fair judicial proceedings

\title{
日本における刑事手続きの通訳 : 過去、現在、今後の展望
}

\begin{abstract}
：日本の歴史において外国人が関わった刑事事件の記録は 5 世紀に遡るが、 司法通訳に関する記述が現れるのは江戸時代からである。1709 年のイタリア人宣教師の 密入国事件や 1865 年のイギリス領事館員によるアイヌの遺骨盗掘事件における尋問者 と被疑者との間のコミュニケーションの難しさは、今日の刑事手続きにも共通するもの である。本稿では、いくつかの有名な事件を軸に、日本の司法通訳の歴史を紹介寸ると ともに、現代日本の外国人が関わる刑事手続きにおけるコミュニケーション問題の変化 について考察する。さらに、裁判員制度導入や捜查の可視化を含む近年の司法改革を背 景に、司法通訳に対する法律実務家の考え方の変化や今後の展望についても論じる。
\end{abstract}

Key words: 歴史、刑事手続き、コミュニケーションの困難性、司法通訳、公正な司 法手続き

\section{TLUMACZENIE PRAWNE SPRAW KARNYCH W JAPONII: PRZESZLOŚĆ, TERAŹNIEJSZOŚĆ I PERSPEKTYWY NA PRZYSZLOŚĆ}

\begin{abstract}
Abstrakt: W istniejącej literaturze przedmiotu opis spraw kryminalnych z udziałem cudzoziemców sięga około piątego wieku. Jednak szczegółowe opisy problemów językowych wymagających udziału thumaczy prawniczych zaczęły pojawiać się w okresie Edo (1603-1868), np. przypadek włoskiego misjonarza, który nielegalnie wjechał do Japonii w 1709 r., a także rabunek grobów Ainu przez brytyjskich urzędników konsularnych w 1865 r., wskazywały na trudności komunikacyjne między śledczym i oskarżonym w postępowaniu karnym. Jest to powszechne nawet dzisiaj. Niniejszy artykuł przedstawia historię thumaczeń ustnych $\mathrm{w}$ odniesieniu do znanych przypadków, a także analizuje zmiany w kwestiach komunikacyjnych w postępowaniu karnym, w którym udział biorą osoby spoza Japonii. Przedstawiono również perspektywy dotyczące zmiany podejścia prawników do interpretacji prawnej na tle niedawnych reform sądownictwa, w tym wprowadzenia ławników i wizualizacji procesu dochodzenia.
\end{abstract}

Słowa kluczowe: historia, procedury karne, trudności komunikacyjne, thumaczenie ustne, sprawiedliwe postępowanie sądowe 


\section{Introduction}

In Japan, the issue of legal interpreting began drawing attention during the economic boom period called 'the bubble economy', which occurred between the latter half of the 1980s and early 1990s. During this period, a large number of immigrant workers came to Japan mainly from Asian and South American countries to fill the workforce shortage. Many of these workers did not speak Japanese. With the increasing number of foreign workers, criminal cases involving non-Japanese speaking people also increased, and a communication breakdown in court, police interrogations, and interviews by defending counsellors emerged as a serious problem. In the last three decades, the government has been addressing this language barrier problem and established a system to recruit legal interpreters, who are appointed to all cases involving non-Japanese speaking defendants or witnesses. However, in terms of quality control, much remains to be done. For example, there is no public certification system or systematic training program for interpreters incorporating proper skills training like that for conference interpreters. Without a certification system, there is no way to detect and dismiss poorly performing interpreters, and without a proper training system, there are no opportunities for interpreters to improve their skills. Recently, the attitude of legal practitioners toward this issue has been gradually changing for the better, and while slow, reform of the system of legal interpreting seems to be moving forward.

Examining history, since the time the nation established laws-nationwide or local, primitive or sophisticated-violators thereof have been tried, judged, and punishments executed. Some criminal cases involved people not able to communicate without the help of interpreters. Political or social situations varied depending on the time, as did how to deal with the crimes. Some periods were characterised by active interchanges with people from abroad, while in others, such exchanges were diminished or prohibited. How people dealt with criminal cases involving foreigners and the communication issues in previous eras are interesting topics to pursue. The present situation of legal interpreting, which has not yet fully matured, and its future prospects can be positioned as an extension of past events. 


\section{Interpreting in criminal cases in old Japan}

\subsection{Ancient times}

In Japanese history, descriptions of criminal cases involving foreigners date back to around the fifth century. Most cases were political or diplomatic including cases of espionage. There was even an adultery case (429) involving a high-class official of the Japanese royal court and a woman presented to the emperor by the Baekje [百済] (ancient Korean kingdom) government (Shigematsu 1986). In those days, many people from China and Korean peninsula played important roles in Japan, which was linguistically international. Thus, many people were likely able to act as interpreters when necessary.

In the official records, interpreting as a profession first appeared in 607. Here, the term 'Osa [日佐]' referred to 'interpreter'. Details of interpreters in the eighth and ninth centuries are clarified in several official documents. In those days, Chinese was regarded the Lingua Franca of East Asia, and was a diplomatic language exclusively used in official scenarios. Furthermore, a national system to train the lowest class court officials as interpreters existed. In addition to China (the then Tang [唐] dynasty), Japan had active exchanges with Balhae [渤海] (a former mixed Korean-Mohe empire that existed from $698 \mathrm{AD}$ to $926 \mathrm{AD}$ in Manchuria) and Silla [新羅](a kingdom located in the southern and central regions of the Korean Peninsula from $57 \mathrm{BC}$ to $935 \mathrm{AD})$. Interpreters of these regions' languages existed and it is likely that in the scenes other than official diplomatic scenes those interpreters were used. It is interesting to compare two cases of the interrogation of foreigners who arrived on ships that drifted onto the shores of Japan. One was a pirate ship from Silla (811 AD), and the other was from Balhae, on board of which was the nation's official delegates to China (873 AD). For the interrogation of the former, the government branch office located in Dazaifu [大宰府] in the northern part of Kyushu [九州] sent a Silla language interpreter (Yuzawa 2010: 122). However, in the latter case, the same government office sent a Chinese language interpreter, despite that those on board the ship were from Balhae (Yuzawa 2010: 78-81). This was likely because this was an embassy ship taking envoys to China; thus, the Japanese side 
may have assumed that some people in the party spoke Chinese. In addition, there was an agreement between Japan and Balhae that Chinese would be used as their official language of communication (Yuzawa 2010: 81-82).

\subsection{The middle ages}

In the Kamakura [鎌倉] era (1185-1333) and Muromachi [室町] era (1336-1573), exchanges with foreign countries centred on economic and cultural aspects. Chinese was still the Lingua Franca, and intellectuals in the countries surrounding China employed Chinese as an official diplomatic language.

The great Yuan [元] dynasty controlled much of East and North Asia between 1271 and 1368, causing great turmoil in the region. Genko [元寇], the Mongolian Invasions of Japan, which took place in 1274 and 1281, were the most noteworthy international incidents in medieval Japan. Before the invasion, the Yuan government sent envoys including people from Goryeo [高麗] (kingdom of Korea; 918-1392), which was under the control of Yuan, to Japan with a letter written in Chinese demanding Japan to become their vassal state. They sent envoys six times. The Japanese government ignored the letters, so Yuan sent their battleships in 1274 to Japan to conquer the country, attacking several islands and Hakata [博多] Bay on the mainland. After the fierce fighting between the allied force of Yuan and Goryeo and the samurai warriors of Japan, ships of the allied force had disappeared next morning. According to the common belief, a great storm struck the area, capsizing most of their ships and killing numerous soldiers, ultimately ending the war. However, in 1275, Yuan again sent envoys to Japan, this time with an official letter from China (then Sung [宋] dynasty) telling Japan that even China had already been conquered by Yuan and Japan should become their vassal state. This time, the response of the Japanese government was simple: They immediately executed the envoys. Yuan sent more envoys, which were again immediately executed by the Japanese government. Finally, in 1281, Yuan sent the naval force to Japan, but this was struck by another heavy storm, which sunk the fleet (Tamagawa Gakuen, Tamagawa University and Taga, Kenji). Yuan's envoys included interpreters, who were 
involved in the negotiations. However, no legal procedures were followed when the envoys were executed, and they did not have the opportunity to be tried in an interpreter-mediated court, but perhaps faced only interpreter-mediated sentencing.

\subsection{The Edo period}

The Edo [江戸] period (1603-1868) was characterised by its seclusion policy. Japanese people were not allowed to go abroad, and foreigners were prohibited from entering Japan. During this period, only Chinese and Dutch merchants were allowed entry to Nagasaki [長崎], a town located in the southern part of Japan. However, the Dutch had to stay in Dejima [出島], a small manmade island.

The system of interpreting by professionals had already been established by the Edo period, having been implemented during the preceding era of trading with Portuguese and Spanish merchants. All interpreters were government officials whose positions had been passed between generations in the same family. There were about 25 venerable interpreter families, among which a strict hierarchy existed. Young children of interpreter families, usually the eldest sons, were sent to the Dutch trading house in Dejima, where they were taught the language by native speakers. After finishing the courses, they were expected to pass exams to work as interpreters. As such, a good system to train interpreters was in place. In addition to interpreting and translation, interpreters were also involved in the trading business (Katagiri 1985: 34-35).

Even in the closed area in Nagasaki, many troublesome incidents involving foreigners, including violence and rioting, occurred. Here, the interpreters played an important role in settling such incidences. In some cases, foreigners tried to smuggle goods into Japan or foreign ships drifted onto Japanese shores. Next, interesting criminal cases involving foreigners in the Edo period are briefly outlined. 


\subsubsection{The Sidocci Case}

In 1708, a Christian missionary sent to Japan from the Vatican, Giovanni Batttista Sidocci, was caught in Yaku Island [屋久島], Kumamoto [熊本], trying to enter the country illegally. He dressed like a Japanese person, but his facial features, which were not Japanese, and inability to speak Japanese immediately exposed him as a smuggler. He was arrested and interrogated by Gen-e-mon Imamura [今村源右衛門], a competent Dutch-Japanese interpreter. As a government official, interpreters often played a role of a bilingual investigator. Imamura found it impossible, however, to communicate with Sidocci in Dutch. Thus, they asked Dutch merchants stationed in Dejima for help, but they were also unable to understand his language. According to a record, he spoke a strange language, a blend between Italian, Japanese, and other languages. Finally, they decided to interrogate him in Latin, which five interpreters intensively learned from the Dutch merchants who understood the language. After ten days of intense learning, the interrogation resumed. It was found that he was sent by the Vatican to missionize the Japanese people. In Japan, Christianity was strictly banned; thus, this was considered a serious case, and Sidocci was sent to Edo where the central government engaged in further interrogation, which was conducted by Hakuseki Arai [新井白石], a renowned scholar and influential politician. Painstaking, the interrogation lasted for four days, and communication through the make-do Latin interpreters was likely very difficult. Sidocci was sentenced to lifetime imprisonment, not the death penalty, which was common for cases related to Christianity. It has been said that his sentence was more lenient because Arai liked his personality. ] (Katagiri 1995: 89-139).

\subsubsection{The case of the robbing of Ainu graves}

This case occurred at the end of the Edo period after Japan's seclusion policy was terminated. Some Japanese ports such as Hakodate[函館], Hokkaido [北海道] had opened to foreign countries. In 1865, the Hakodate magistrate, Koide Yamato-no-kami [小出大和守], went to the British Consulate to complain that three consulate officers had 
stolen the remains from graves in an Ainu [アイヌ] village (Hori 2011: 263). At the time, anthropological interest in the Ainu aborigines had increased among European scholars, who eagerly wanted to obtain the bones of these people. This is merely one case involving the stealing and secret shipping of Ainu bones.

The magistrate, Koide, took a firm attitude toward the consulate officers who had stolen the remains, although at the time, most Japanese government officials bent to the pressures of advanced Western countries. He tried to conduct a full investigation to clarify the facts. During this period, the extraterritorial rights of foreigners meant that Japan could not bring these suspects to court for trial. Thus, it was important to prepare fairly gathered irrefutable evidence to convince the Consul to incriminate the suspects. Therefore, an excellent interpreter was crucial.

Until Japan opened, Dutch was the primary language for interpreting. After the country opened, other languages became important, especially English. Training English interpreters was an urgent need for Japan. As the northern entrance to Japan, English learning was very active in Hakodate, which housed a group of excellent English interpreters. These well-trained interpreters were all sent to Edo, the political centre of Japan, upon the request of the central government, which had to negotiate with delegates from foreign countries in the surrounding areas, which were characterized by a serious shortage of English-speaking interpreters. To replace those interpreters, the central government sent Tatsunoseke Hori [堀達之助] to Hakodate, a famous Dutch interpreter who was also well versed in English. He compiled the first English-Japanese dictionary in Japan. However, it was revealed during the case investigation that Hori was not good enough as an interpreter, because his English was 'book English'. He had learned English from books and his conversation ability was poor. The magistrate, Koide, petitioned the central government, requesting that one of the English interpreters trained in Hakodate or any other good English interpreter be sent. Koide might have been the first legal officer in Japan who strongly appealed the importance of good interpreting in judicial proceedings.

Fortunately, the government minister of Britain, Parkes, took the case seriously, and decided to dismiss the British consul and punish the three consulate officers. The bones from the Ainu graves had already been shipped to Britain, but through Parkes' efforts, were 
retrieved at customs and sent back to Hokkaido. Furthermore, the Ainu people were monetarily compensated (Yoshimura 1991: 256-304, Mizuno 2005: 24-25).

\section{Interpreting in criminal cases in the modern era}

\subsection{Under the old law}

After the end of the Edo period (1603-1868), as part of Japan's modernisation and influenced by the laws of Western countries, especially Germany, the criminal justice system was reformed. In the modern legal system, equality under the law was guaranteed to a certain extent. However, interpreting for non-Japanese speakers during criminal proceedings did not seem to be an issue of concern. While this was a matter of procedure, interpreting was not necessarily considered in the context of human rights issues.

For example, in the opium smuggling case in 1906, the Supreme Court decided that the non-Japanese speaking defendant must be made aware of the content of the sentence; thus, an interpreter had to be provided at the time of sentencing. Another example stems from 1936, when a decision by the High Court in colonial Korea found it illegal that an interpreter had not been provided at the sentencing of the non-Japanese speaking defendant at the first trial. However, since the sentence was appealed to a higher court within the period specified by the law, the ruling of the lower court did not need to be overturned (Tanaka 2006: 6). Providing an interpreter for the entire proceedings was not the norm at that time, and the defendant's right to be both physically and mentally present at the proceedings was not a commonly accepted idea.

\subsection{Present situation}

After World War II, under the occupation policies of the GHQ (General 
Headquarters, the Supreme Commander for the Allied Powers), Japan established a new legal system as part of the democratisation of the nation. The Code of Criminal Procedure was based on the adversarial system, and as such was influenced by the law practiced in the US.

Throughout history, the issue of interpreting in criminal cases has evolved around two main points: the presence of an interpreter and the quality of interpreting. As Japan's democratisation has advanced, especially after World War II, the presence of an interpreter has become a norm in the light of human rights of non-Japanese speakers and the main issue has shifted from the presence to the quality of interpreters.

\subsubsection{System of appointing interpreters}

Although the Japanese Code of Criminal Procedure does not stipulate court interpreting as a defendant's right, based on the International Covenant on Civil and Political Rights, which the Japanese government ratified, and Article 31 of Japan's Constitution, which guarantees the due process of law in criminal proceedings to everybody, the right of the defendant to participate physically and linguistically in criminal proceedings must be fully guaranteed to foreigners in Japan. Over the past three decades, the system of appointing legal interpreters has improved significantly in each judicial branch in Japan. In most cases, the right of non-Japanese speaking suspects to an interpreter of their native language is now guaranteed.

\subsubsection{Issues of quality control}

Thus far in Japan, no public certification system exists for legal interpreters. For example, candidates for the position of a court interpreter are interviewed by a judge and questioned on their language ability, overseas experience, interpreting experience, and so on. Sometimes, a so-called 'veteran' interpreter works with the judge to check the language ability of the candidates, but there is no test for their interpreting skills. Consequently, even those who have not undergone training are often registered as interpreters. 
Three types of training programs for interpreters are provided by district courts countrywide, namely an introductory program for newly registered interpreters, a seminar for interpreters who have some interpreting experience, and a follow-up seminar for very experienced interpreters (General Secretariat, Supreme Court of Japan 2017). The courses are conducted for two days once a year, and are only available to interpreters of certain languages. Furthermore, the courses focus on improving knowledge of legal procedures and legal terms, as well as interpreters' ethics, although scant attention is paid to training in interpreting skills. This is true for other judicial branches as well. Under such circumstances, while abilities vary between interpreters, it is not possible to exclude those who perform poorly. Thus, in several cases, inaccurate interpreting became an issue, and sometimes constituted grounds for an appeal.

\subsubsection{Pakistani robbery case (1992)}

This case involved a robbery and robbery resulting in injury. Two of the three Pakistani suspects were from a Panjabi speaking district; however, the interpreter assigned to the interrogation was an Indian who spoke Urdu mixed with some Hindi. The suspects only understood around a third of what the interpreter said. The case was appealed to a higher court for the reason that using the statements made during the interrogation, in which the suspects did not fully understand what was said, as evidence in court violated the 'linguistic due process' guaranteed by Article 31 of the Japanese Constitution. However, the appeal court upheld the decision of the district court, stating that considering the reality that it is difficult to find interpreters of languages of lesser diffusion in local cities, appointing an Urdu speaking interpreter for the suspects, whose first language was Panjabi, was lawful, because the suspects had some understanding of Urdu (Oda 2014: 77-78). 


\subsubsection{The Dogo case (1996)}

The next case is one of a homicide in which the defendant was a Thai woman working as a prostitute in Dogo [道後], Ehime [愛媛]. She killed her manager, another Thai woman. The appointed interpreter was a Japanese woman who had been in Thailand for two years after her husband's transfer. Her Thai language ability was very poor, and she was unable to translate even simple words. Often, she could only simplify difficult Japanese words or point to words in the dictionary. The case was appealed to a higher court, where a Thai interpreter with experience in legal interpreting was appointed. However, this interpreter was also unable to accurately translate the defendant's statements into Japanese, and ultimately, the appeal was dismissed. The court admitted that the quality of interpretation in the first trial was low, but decided that the defendant's Japanese proficiency was sufficient to understand the court proceedings (Fukami 1999). This is a typical case at the time, when it was difficult for the court to find interpreters of less widespread languages such as Thai. In many cases, so-called 'ad hoc interpreters' had to be used.

\subsubsection{The Nick Baker case (2005)}

In this case, a British citizen allegedly smuggled drugs into Japan. $\mathrm{He}$ was tried at the Chiba district court, where he was found guilty and sentenced to 14 years of imprisonment with forced labour and fined 5 million yen. However, he appealed to the Tokyo High Court, and his sentence was consequently reduced to 11 years of imprisonment and the fine to 3 million yen. There were several reasons for the appeal, one of which was poor interpreting. The defence submitted the expert opinion paper on the accuracy of the interpreting (written by the author) to the court.

Two main factors caused the interpreter-induced communication failure in this case. One was the defendant's heavy cockney accent, which made it difficult for the court interpreter to fully understand his speech. The other was the unethical behaviour of the court interpreter, who failed to inform the court that she did not fully 
understand the defendant and continued interpreting his statements. Consequently, the defendant's long statements were translated into extremely short sentences, and important pieces of information omitted. Furthermore, nuances or the impacts of the original statements were distorted or reduced, and confusion created, which fuelled the negative impression of the defendant that his speech was incoherent. In addition, some mistranslations gravely impacted the case, such as in the example provided below.

During the witness examination, the defendant was asked the following question: "What did you say when the customs official at the airport asked you if he may X-ray the suitcase?' The defendant answered that he had told the customs official, 'It ain't mine (It is not mine)'. This was translated by the interpreter as 'I do not mind'. One point at issue in this case was whether the suitcase containing the drugs belonged to him or not; thus, this is a serious misinterpretation (Mizuno 2008).

\section{Judicial reform and recent trends in criminal proceedings}

\subsection{Introduction of the lay judge system}

In 2009, as part of the judicial reform, Japan introduced the lay judge system. In this system, six citizens are randomly selected from the voter rolls to serve as lay judges, and alongside three professional judges, decide whether a defendant is guilty. In the case of a guilty verdict, the lay judges collaborate with the professional judges in deciding the sentence. In lay judge trials, felonies such as murder, arson, and the smuggling of illegal stimulants, which can involve the death penalty or imprisonment without a fixed term, are adjudicated. The purpose of the system is to make criminal procedures understandable for ordinary people. However, the new system has posed new challenges for court interpreting. Unlike conventional trials that emphasise documentary evidence, testimony is regarded more important in lay judge trials, because that orally presented in court is the only evidence on which to base the judgment, increasing the responsibility of court interpreters. 
According to Hotta (2009: 122, 2010: 87), lay judges tend to pay more attention to the mental aspects of a defendant, and base their decision on factors such as character and mental tendencies, and whether the defendant deserves their sympathy. This implies that they are likely to be influenced by the impressions created through testimonies. As such, not only what is spoken, but also how it is spoken is of great importance.

Many studies confirm that the way interpreters interpret (or speak) impacts hearers such as jurors and lay judges, who form an impression and evaluate witnesses or defendants based on the interpreter's delivery (Hale 2004, Berk-Seligson 2000, Nakamura and Mizuno 2010, etc.). To secure a fair trial, interpreters should be highly skilled in translating the nuances and registers of statements provided in court.

\subsection{Visualisation of interrogation}

To avoid false charges, the system for the visualisation of investigation has been introduced as part of the judicial reform. One major change was introducing video recordings of the interrogation process of all lay judge trials. To pilot this change, partial video recordings of a small number of cases were initiated in 2006 at the prosecutors' offices and in 2008 at police stations. The number of cases now recorded has increased since then. In 2014, cases involving defendants that were mentally retarded or had developmental or mental disorders were added as subject cases. From October 2016, it has been mandatory in principle to video record the interrogation of all lay judge cases.

\subsection{Problematic cases tried in the lay judge court}

\subsubsection{The Bernice case (2010)}

The Bernice case involved charges of smuggling stimulant drugs. The 
defendant, a German national from South Africa whose mother tongue was English, attempted to smuggle drugs into Japan, but was caught at Kansai airport. She claimed she had been asked by her acquaintances to take the 'stuff' to someone in Japan and bring money back to South Africa without knowing what the 'stuff' was. She was sentenced to nine years imprisonment with labour and was fined 3.5 million yen. She appealed the case to a higher court, claiming that because of the poor quality of interpreting in the first trial, her right to a fair trial had not been guaranteed. To prove the inadequacy of the interpretation in the lower court, the defence lawyer commissioned four linguists including the author to write expert opinions based on the audio recordings of the first trial, which were submitted to the higher court. The expert opinion reports pointed out many mistranslations and pragmatic alterations to the original statements, some of which may have seriously impacted lay judges' impressions and decision making.

However, the prosecutor refused to accept the expert opinions, maintaining that the quality of the interpretation was acceptable. The appeal court held that the expert opinions were irrelevant and dismissed the appeal. According to the judge, the experts only highlighted minor elements, the impacts of which on the lay judges could not have been significant, assuming that completely accurate interpretation is impossible and minor errors are acceptable. The judge did not consider the linguistic analysis of the court interpretation important, and disregarded the 'power of language' (Watanabe 2012, Nakamura 2013).

\subsubsection{The Jakarta case (2016)}

This is a case involving a defendant, a former member of the Japanese Red Army, who bombed the Japanese and US embassies in Jakarta in 1986. He was arrested in 1996 in Nepal where his hiding place was and sent first to the US for trial. After serving his sentence in the US, he was rearrested by the Japanese police in 2015 and tried in the Tokyo district court. One of the two interpreters assigned to the case demonstrated poor interpreting skills, making many mistakes based on not understanding even basic Indonesian words such as refrigerator and paper. There were also many incorrect translations, for example, 1000 lupia was translated as 100 , and 83 years as 85 years. Expert 
examinations on the accuracy of the interpreting were conducted on the request of the presiding judge, revealing around 200 mistakes (Ikeda and Misawa 2016). This case is noteworthy, because it was the first time a judge had ordered expert examinations on court interpreting during the first trial.

\subsubsection{The Osaka murder case (2017)}

In this case, a Chinese man killed his wife in Osaka [大阪]. The presiding judge of the first trial noticed a discrepancy between the contents of the written statement taken at the police interrogation and the defendant's statements during the trial concerning the most important point: Whether the defendant had murderous intent or not. The judge doubted the accuracy of the interpreting during the investigation, and ordered that an expert analysis be conducted of the DVD recordings of the interrogation to confirm. The analysis revealed approximately 100 omissions and 20 misinterpretations (Yomiuri Newspaper 2017). The introduction of video recording of interrogations has now made it possible to verify the accuracy of interpreting in the investigation stage. This is an important step toward fair criminal proceedings. Thus, it is desirable to expand the scope of visualisation to include all cases other than lay judge cases.

\section{Changes in attitude among legal practitioners}

In recent years, legal practitioners' understanding of the importance of quality legal interpreting has increased. For example, the Japan Federation of Bar Associations prepared its 'Opinion Concerning the Proposal for Legislation Regarding Court Interpreters' dated July 18, 2013, and submitted it to the Chief Justice of the Supreme Court, Minister of Justice, and Prosecutor General. The contents thereof are summarised below.

1. Regarding court interpreters at criminal trials, etc., the following matters should be stipulated by law: 
(1) The establishment of a system that lists the names of interpreters based on their qualifications, in order to ensure the quality and abilities of interpreters.

(2) The establishment of a system that provides continual training for interpreters, so as to maintain and improve their abilities.

2. Regarding court interpreters at criminal trials, etc., the following matters should be stipulated in the Rules of the Supreme Court (Rules of Criminal Procedure), etc.:

(1) The establishment of a remuneration system that guarantees secure income for interpreters.

(2) Regulation of the following matters, so as to ensure the quality of interpreters in open court:

a) Selection of multiple interpreters, as a general rule, in order to prevent the occurrence of incorrect interpretations.

b) Mandatory provision of opportunities allowing interpreters to have advance preparation for trials.

c) Stipulation on such issues as audio recording, objections, and expert examination for after-the-fact verification.

d) Obligation of consideration by case-related persons in general and in making efforts to provide the case-related documents in advance.

e) Obligation of consideration by courts in general and when the sentence is handed down at court.

(The Japan Federation of Bar Associations)

Against this background, the Japan Federation of Bar Associations has held several events to enlighten lawyers and legal interpreters about the mechanism of interpreting. For example, they have held a symposium on collaboration between interpreters and legal practitioners in lay judge trials (September 2014), a training session to improve the skills needed for court interpreting and court questioning (December 2015), and a training session on court interpreting focusing on note-taking and memory mechanisms (August 2017). In March 2017, the Japan Federation of Bar Associations also produced 60-minute content for e-learning purposes to improve member lawyers' questioning skills in interpreter-mediated trials. In addition to these activities, linguistic analysis research on the accuracy of court interpreting was conducted in collaboration with lawyers, experienced 
legal interpreters, and linguists including the author. Various problems generated from the ways lawyers speak during the questioning sessions in court were discussed, a guidebook on practices in interpreter-mediated court questioning issued (KAKENHI [Grants-in-Aid for Scientific Research], Grant number: 26370514, Title: Research on the language use of lawyers in court and interpreter-induced alterations and their impact on court room communication), and research papers based on the above published (Mizuno 2015, Mizuno 2016, Mizuno, Terada and Ma 2016)

April 2017 witnessed a noteworthy development in terms of government-academia collaboration. The Tokyo District Public Prosecutors Office Public Security Bureau and Center for Multilingual Multicultural Education and Research at Tokyo University of Foreign Studies signed a memorandum of understanding for cooperation to promote smooth communication in a multilingual and multicultural society and foster quality interpreters. As part of the collaboration, they hold several events such as students' visits to the Tokyo District Public Prosecutors Office and Tokyo District Court, and a mock interpreter-mediated trial at the open campus of Tokyo University of Foreign Studies (Tokyo University of Foreign Studies). This collaboration seems effective in fostering good human resources in the younger generations.

\section{Conclusion}

A review of the history of legal interpreting in Japan clarified that at any time - ancient, feudal, or modern-linguistic communication has been essential in criminal procedures. While human beings have systems in place to try and punish violators of their rules, language will remain an integral part of the process. The extent to which those who are tried and judged can have their case heard is a barometer of the maturity of society. The system of and attitude toward legal interpreting constitute part of this barometer.

Currently, the idea of due process and equality under the law is deeply rooted in most advanced nations worldwide, which have been addressing the issue of communication in criminal proceedings involving those who do not speak or understand the language used to 
ensure a fair process.

Providing quality interpreting and translation services has been a major challenge in this context. Now, Japan is one such nation. Despite that Japan has no certification system for legal interpreters yet, efforts have been made to improve the situation. Awareness of the importance of accurate interpreting has risen among legal practitioners, as reflected in the various recent actions mentioned in the previous section. To advance, it will be necessary to consider implementing a system to train and certify legal interpreters and conduct further research on the linguistic analysis of interpreting. Furthermore, a training method for interpreters and ways to enhance lawyer-interpreter collaboration will be needed. Such efforts will help create a brighter future for legal interpreting.

\section{Bibliography}

Books and articles

Berk-Seligson, Susan. 2002. The bilingual courtroom: Court interpreters in the judicial process. Chicago: University of Chicago Press.

Fukami, F. 1999. Tsūyaku no hitsuyō wa arimasen: Dōgo tai josei satsujin jiken saiban no kiroku [There is no need for interpreting: Record of a Thai woman's murder trial in Dōgo]. Matsuyama: Sōfūsha.

General Secretariat, Supreme Court of Japan. 2017. Gozonji desu ka hōtei tsūyaku [Do you know court interpreting?](pamphlet)

Hale, Sandra. 2004. The discourse of court interpreting. Amsterdam/Philadelphia: John Benjamins.

Hori, Takahiko. 2011. Kaikoku to ēwa jiten [Opening of the country and English-Japanese dictionary]. Kamakura: Minato no-hito.

Hotta, Shugo. 2009. Saiban to kotoba no chikara [Trials and the power of language].Tokyo: HituziShobō.

Hotta, Shugo. 2010. Hō kontekisuto no gengo riron [Linguistic theory in the legal context].Tokyo: HituziShobō.

Katagiri, Kazuo. 1985. Oranda tsüji no kenkyū [Study on interpreters 
between the Dutch and Japanese].Tokyo: Yoshikawa Kobun kan.

Katagiri, Kazuo. 1995. Oranda tsūji Imamura Gen-emon Eisei [Dutch-Japanese interpreter, Gen-emon Imamura Eisei]. Tokyo: Maruzen Library.

Mizuno, Makiko. 2005. Historical review of criminal cases involving foreigners and legal interpreting. The Journal of Senri Kinran University 2: 21-29.

Mizuno, Makiko. 2008. Nick Baker case: The challenges encountered in improving the quality control of legal interpretation in Japan. Kinjo Gakjuin Daigku Ronshu Studies in Social Science 5, 1: 34-41.

Mizuno, Makiko. 2015. The sentence-ending particle Ne used by lawyers in cross-examination and its English interpretation. Language and Law 2: 85-105.

Mizuno, Makiko. 2016. Double negative questions used at witness examinations and their interpretation. Kinjo Gakjuin Daigku Ronshu Studies in Social Science 12: 1-6.

Mizuno, Makiko, Yumiko Terada and Xiaufei Ma. 2016. The issue of court interpreting: Roundabout expressions and ambiguous wording used by lawyers in court. Language and Law 3: 61-80.

Nakamura, S. 2013. Issues of interpreting in the Bernice case. Language and Law 1: 27-37.

Nakamura, Sachiko, and Makiko Mizuno. 2010. Court experiment: Impact of interpreting on impressions of mock lay judges. A statistical study of language use in trials under the lay judge system. The Institute of Statistical Mathematics Cooperative Report 237: 53-66.

Oda, Itaru. 2014. A study on legal interpretation and selection of source language: Based on cases with Chinese dialects. The Bulletin of Chuo University Institute of Cultural Science 79: 63-116.

Shigematsu, Kazuyoshi. 1986. Gaikokujin keiji hōsei taikeika e no shiteki shiron: shijitsu, bunken no shōshū to taishō ryōiki no tansaku [Historical essay on the systematization of the criminal legal system involving foreigners: Collection of historical events and literature and exploration of the object domain]. The Bulletin of Chuo Gakuin University Sogo Kagaku Kenkyujo (research material) 3: 29-57.

Tanaka, Yasuha. 2005. Gaikokujin jiken to keiji shihōu: tsūyaku wo 
ukeru kenri to shihō tsūyakunin ni kansuru ichikousatsu [Cases involving foreign nationals and criminal justice: Discussion on the right to interpreters and legal interpreter]). Hokkaido University Graduate School of Law, Junior Research Journal 12: $1-41$.

Yoshimura, Akira. 1991. Kurofune [Black ships]. Tokyo: Chūō kōron sha.

Yuzawa, Tadayuki. 2010. Kodai nihonjin to gaikokugo [Ancient Japanese people and foreign languages]. Tokyo: Bensei shuppan.

Watanabe, Osamu. 2012. Saiban-in saiban to "goyaku enzai": Garusupaha Benīsu jiken [Lay judge trial and "wrongful conviction due to misinterpretation": Bernice Gerspacher Case]. In Mitsui Makoto Sensei Koki Shukuga Ronbunshū [Essays to celebrate Professor Makoto Mitsui's $70^{\text {th }}$ Birthday], ed. M. Inoue and T. Sakamaki, 725-750. Tokyo: Yūhikaku.

Newspapers

Ikeda, Teiichi and Noritake Misawa. 2016. Hotei tsūyaku, mondai darake [Court interpreting, so many mistakes]. Tokyo Newspaper, October 18.

Yomiuri Newspaper. 2017. Torishirabe tsūyaku misu 120 ken cho [Over 120 interpretation errors at interrogation]. May 24.

Websites

Tamagawa Gakuen, Tamagawa University and Taga, Kenji. Genko wa naze okita $\mathrm{ka}$, nihon wa dō kawatta ka [Why Mongolian invasion occurred and how Japan changed]. http://www.tamagawa.ac.jp/sisetu/kyouken/kamakura/genkou/i ndex.html (accessed April 15, 2018).

The Japan Federation of Bar Associations. Opinion Concerning Proposal for Legislation Regarding Court Interpreters. https://www.nichibenren.or.jp/en/document/opinionpapers/201 30718.html (accessed May 5, 2018).

Tokyo University of Foreign Studies. Center for Multilingual 
Multicultural Education and Research http://www.tufs.ac.jp/blog/ts/g/cemmer/news/post-23.html (accessed June 14, 2018). 